\title{
OBSERVATION ON DUST ATTACHMENT IN EPIPHARYNX WITH NASAL SEPTUM DEVIATION
}

By

\author{
SINSAK HORIGUTI and $\mathrm{Y}_{\text {ASUO IDE }}$
}

\begin{abstract}
From the Department of Oto-Rhino-Laryngology, School of Medicine, Tokyo
\end{abstract} Medical and Dental University (Director: Prof. S. Horiguti)

It has been known that in the case with nasal septum deviation, the inflammation is apt to be caused in the epipharyngeal region corresponding to the convex side of nasal septum and the severer is the deviation, which causes greater nasal obstruction on the convex side, the more remarkable become the localization of inflammation in the epipharyngeal region to the same side. As one of the most important causes of the above-mentioned phenomenon, it can be considered that the abnormal air current in epipharynx due to unilateral nasal obstruction will cause the condition in which the dusts in the air are liable to attach in the epipharyngeal region to the convex side. Observation was therefore made on the dust attachment in the epipharynx with experimental nasal septum deviation.

The result showed that the attachment of dust was of a higher degree in the epipharyngeal region to the convx side quantitatively and also their size was rather large on the convex side.

\section{鼻中隔彎曲における鼻咽腔の麘埃付着状態の観察}

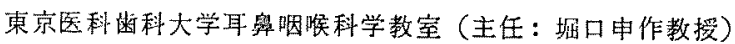

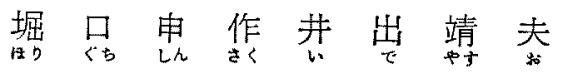

\section{はじめに}

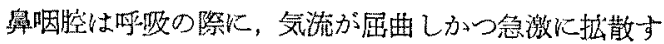
る場所であるため，麼埃・細菌等がその壁に付着しやす く，その刺激によつて炎症が萎起しやいであるらといら ことは，容易に推定されるところである。

私達はすでに鼻中隔禁曲例について，その鼠咽腔の炎

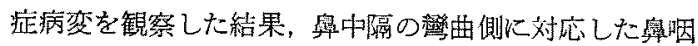
空部は，他側に比して炎症からより高度になる傾向のある ことを報告し ${ }^{7}$ ，更に鼠空通気の左右差を客䂓的に测定

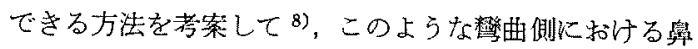

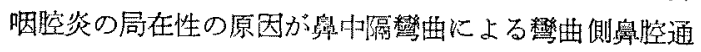
気障害によるものであることを明らかにした 910 1)。

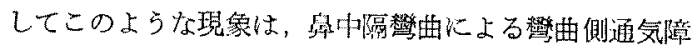

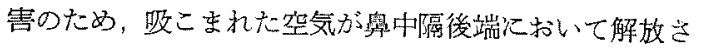

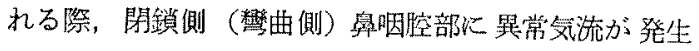
し，空気中の蝔埃・細菌等がこの部位に，上り付着しゃ すい状態を招来せしめるために生したものであるらと考
察した。

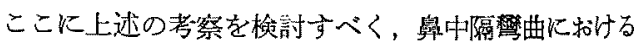
舜咽腔各壁の磨埃付着状態を，模型鼻腔を用いて実験的 に調べたので，その結果について報告する。

\section{実戨装置}

笋賖装置は第1図に示寸如くで，先に富井2が発表 したものる簡略化したものである。

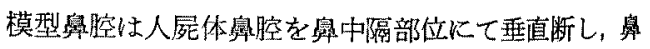
中隔を除去アアルデックス扰よび石臂を用いて左右それ ぞれ2つの舆腔を作り若干の修正を加点て, 可及的生体 让常鼻腔に近い形態となしこれを更にアクリル樹脂に

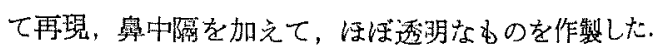

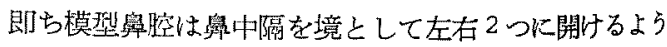
に作つた。

図に示す B は発塵装㽡で，この中に一定流量の空気 を送るＣは塺埃浮游貯溜槽で，空気中に発塵したも のがなるべく均一になるように設けたものである。 
第 1 図実酠装置

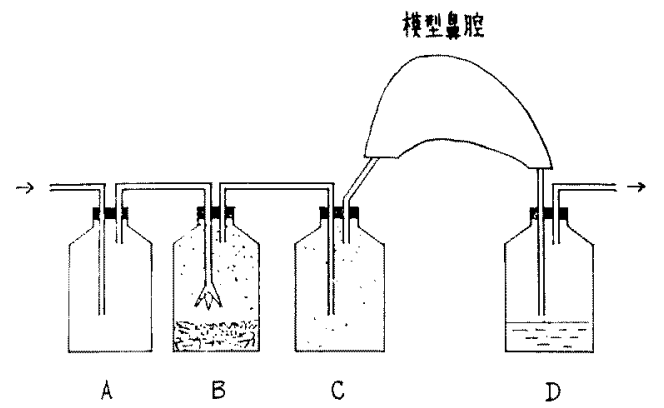

D は楀腔・鼻咽腔通過後の塵埃貯溜槽で，これに上り 吸引蓄置の防蓹を行い，一定圧で呚引した。富井は A と B の間拉上び D の後に流量計学㨉入して，流量を 調節できるようにしているが，鼻咽腔壁の鷹埃付着状態 の大要を知るには上記の畒置で差支えないと考宎た。 なお，塵埃以は酸化フルミニウム粉末を用いた。

\section{実験方法}

付着麘埃の採取：鼻咽腔の 軟口蓋背面, 耳管隆起, 天蓋のそれ艺れ左右 6 ケ所に $0.5 \mathrm{~cm} \times 0.7 \mathrm{~cm}$ の大きさの 薄紙を水に浸して貼存して, 左右稇腔を合せてとめ, 接 合部をテープにて密閉して，蝔埃含有空気を一定時間通 過させ，しかる後に鼻腔を左右に開いて帖布せる應埃付 着薄紙をとり出し：これを $1 \mathrm{cc} の$ 蒸溜水中に入れてよ く摫䢁し塵埃浮游液とした。

塵埃の計測：塵粒子の量についてはこの塵埃浮游液 の一谪を Thoma の血算板を利用して，油搌装置下に 算定し，粒子の大きさは同しく油浸装置下にて micrometer を用いて測定し，その\%をだし各部位における 鷹粒子量および粒子の大きさの相異による分布を調べ た.

鼻中隔の攀曲作製：先の研究 9)で鼻中隔禁曲が最も 通気状態を覀くするのは，舆中隔軟骨全体が偏位する場 合であることが判明したので，この部位に繁曲を作るこ

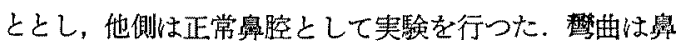
中融片側の中隔軟骨に相当する部分にパラフインを塗布 して作製し，この部が中・下身介ときつく接するものを

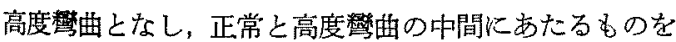
中等度慧曲とした。

\section{実 唫結果}

正常に郝ける塵埃付着状態

先す模型丼腔に標曲がない場合（正常）について，そ の鼻咽胵塵突代着状態を観察し，ほとんど左右差なく分
布するのを認めた。

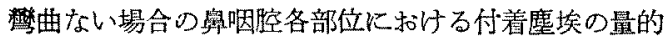
差異は第 2 図に示した，軟口蓋污け可付着量を $100 \%$ とすると，耳管隆起は $74.0 \%$ ，天蓋は $24.7 \%$ であつて 軟口蓋に付着する量が最も多い，歴粒子の大きさによる

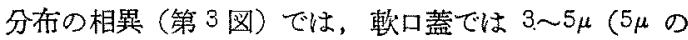
ものが最も多い）のものが多く付着し，耳管隆起・天蓋

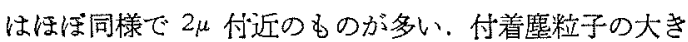
さの平均は軟口蓋 $4.0 \mu$, 耳管隆起 $2.9 \mu$, 天蓋 $2.8 \mu$ で, 軟口蓋には比較的大きい粒子が 付着しやすいと思われ る.

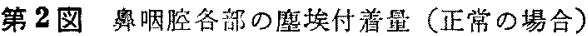

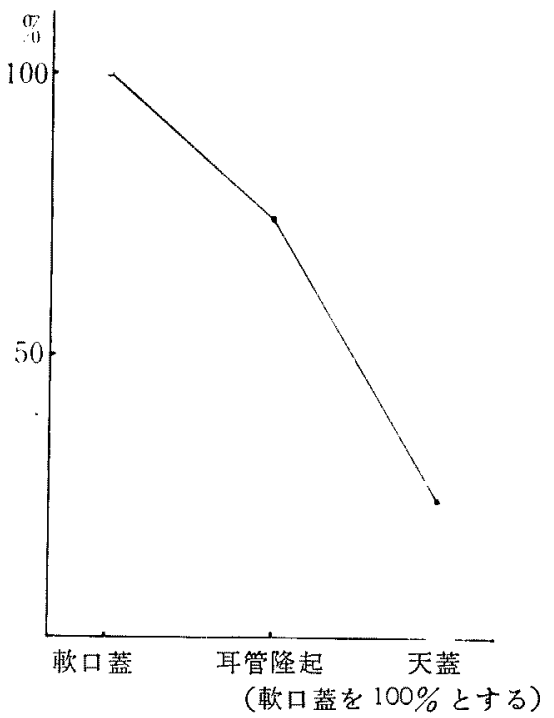

第 3 図曻咽腔各部付着磨埃の大ささの分布 (正常の場合)

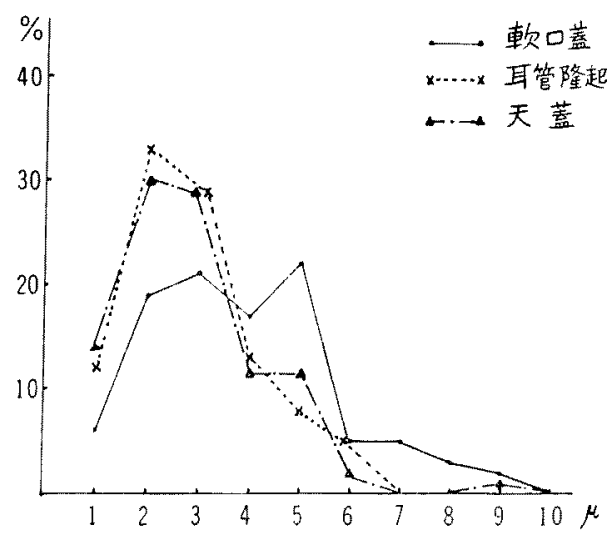


高度慗曲に括ける蝔埃付着状態

各部位付着塵埃の量的な差異については第 4 図に示 した．彎曲側の軟口蓋を $100 \%$ とすれば，同耳管隆起 $74.1 \%$, 同天蓋 $63.8 \%$ であり, 非彎曲側の乾口蓋 34.5 $\%$ ，同耳管隆起 $27.6 \%$ ，同天蓋 $17.3 \%$ となり，警曲側 軟口蓋で最も蝔埃が付着しやすい。

付着歴粒子の大きさによる分布の相異についてみる

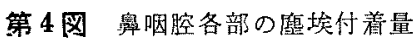

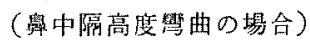

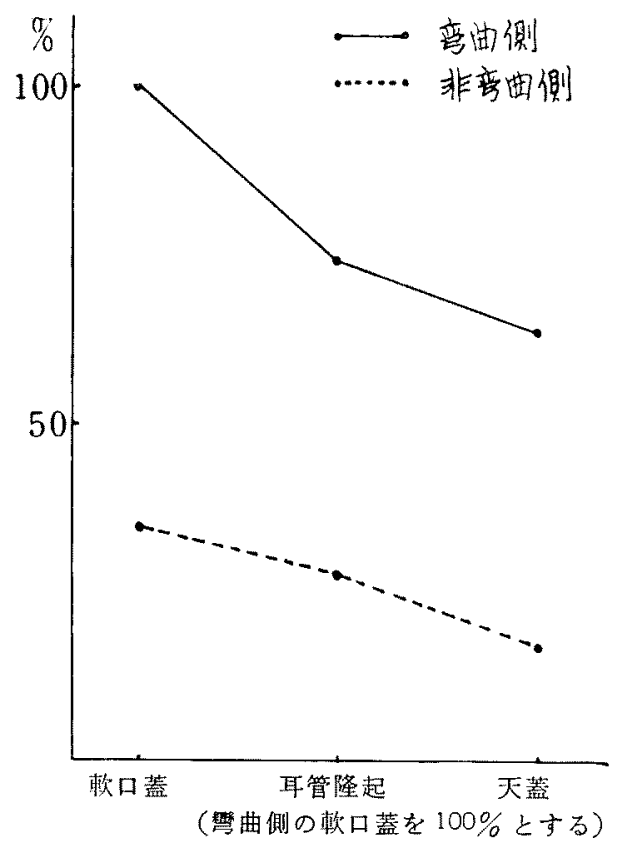

第 5 図 颠口蓋付着鷹埃の大きさの分析 （鼻中隔高度禁曲の場合）

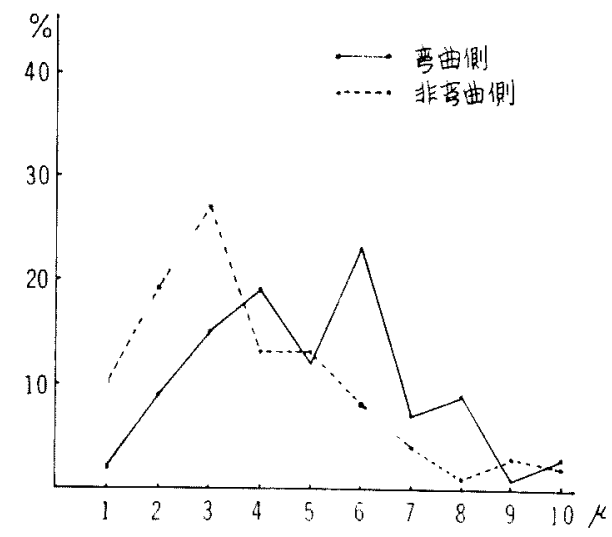

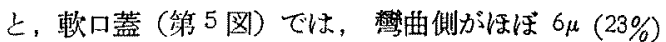
のものを頂点とし，非慗曲側では $3 \mu(27 \%)$ のものを 頂点として分布している，辟粒子の大きさの平均怯，彎 曲側 $5.1 \mu$, 非暜曲側 $3.7 \mu$ である.

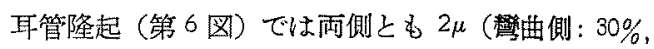
非椋曲側：34\%）のものを頂点として分布し，軟口蓋に 此して著明な左右差はない，麘粒子大きさの平均は彎曲 側 $3.7 \mu$, 非楼曲側 $3.0 \mu$ である.

天蓋（第7 図)では，彎曲側は $3 \mu(26 \%)$ ，非彎曲側 は $2 \mu(31 \%)$ のものを頂点とし，警曲側でやや大るい 粒子が付着しているが，やはり軟口蓋に括ける程の差は ない，麇粒子大きさの平均は敬曲側 $3.4 \mu$, 非整曲側 2.9 $\mu$ である。

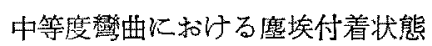
付着塺埃の量的な差異（第 8 図）は埶曲側の軟口蓋を

第 6 図耳管隆起付着塺埃の大ささの分布 (鼻中隔高度鹟曲の場合)

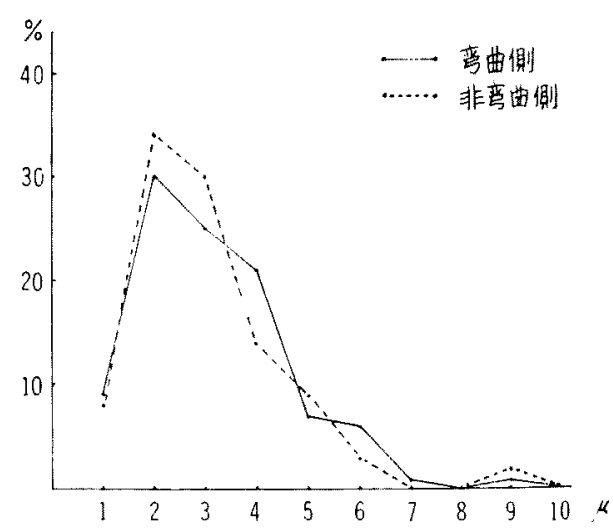

第7図 天蓋付着塺埃の大きさの分布 （菑中隔高度慗曲の場合）

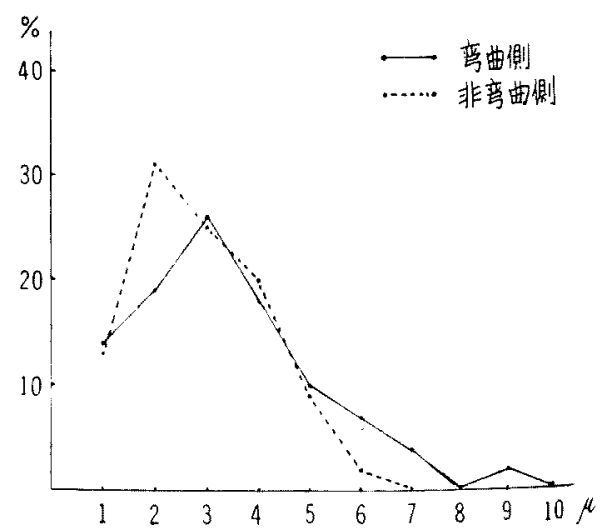


第8图奥咽腔各部の㠊埃付着量

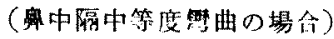

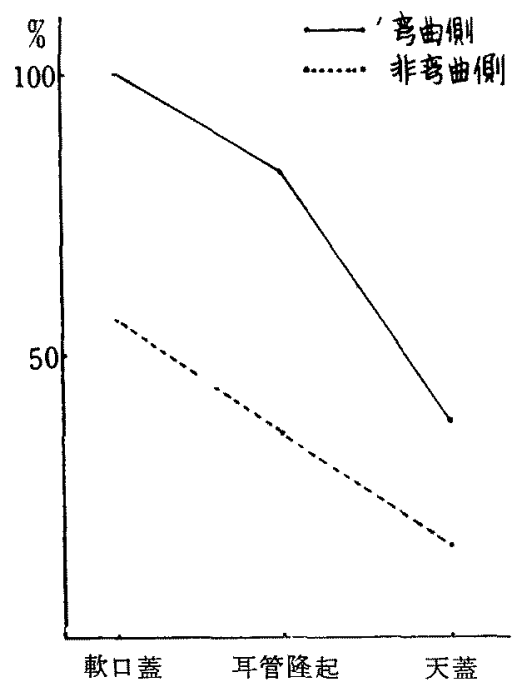

（等曲側の軟口菜を $100 \%$ とする）

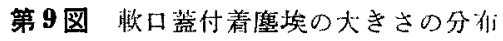

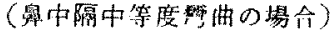

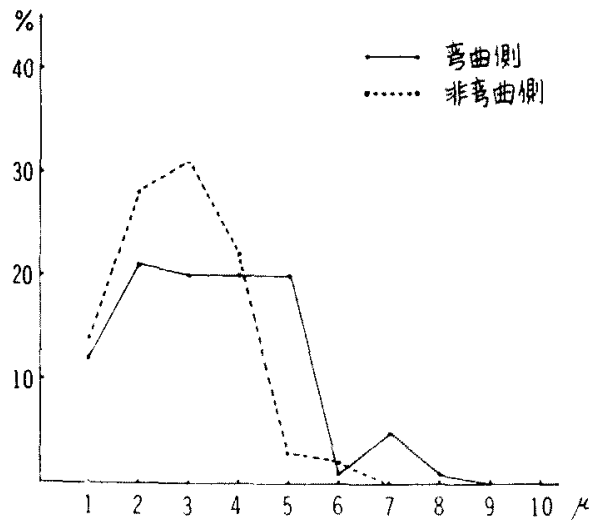

$100 \%$ とすると，同耳管隆起 $82.3 \%$ ，同天蓋 $38.9 \%$ と なり，非鳘曲側では軟口葢 $56.4 \% ，$ 年管隆起 $36.0 \%$ ，

天蓋 $16.4 \%$ である，概して高度慗曲における程ではな

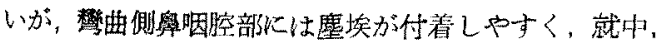
その軟口蓋をもつて最大とする。

付着麇粒子の大ささの相異に上る分布は，軟口蓋（第 9 图)では，攀曲側は非謷曲側に比してやや大きいもの が付着しやすく，その大きさの平均は㷊曲曲側 $3.4 \mu$, 非繁 曲側 $2.9 \mu$ である，耳管隆起（第10图）では，䇾曲側 では $3 \mu(37 \%)$, 非䇾曲側では $2 \mu(38 \%)$ のものを頂点
第 10 图 耳管隆起付着塺埃の大きさの分布

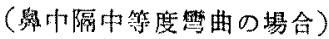

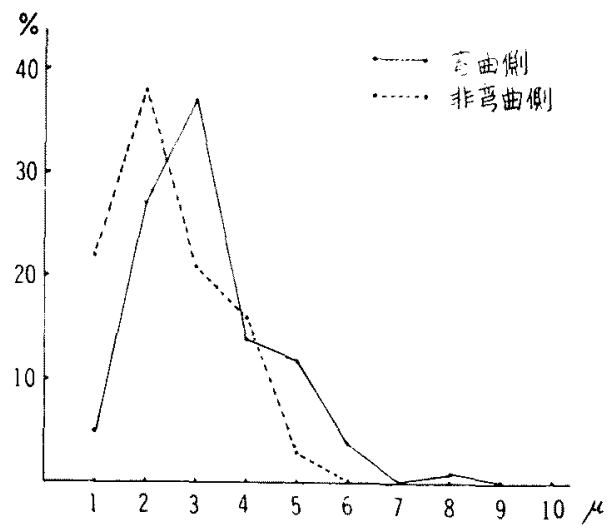

第 11 图 天䕊付着㱆埃の大きさの分布 （舜中隔中等度學曲の場合）

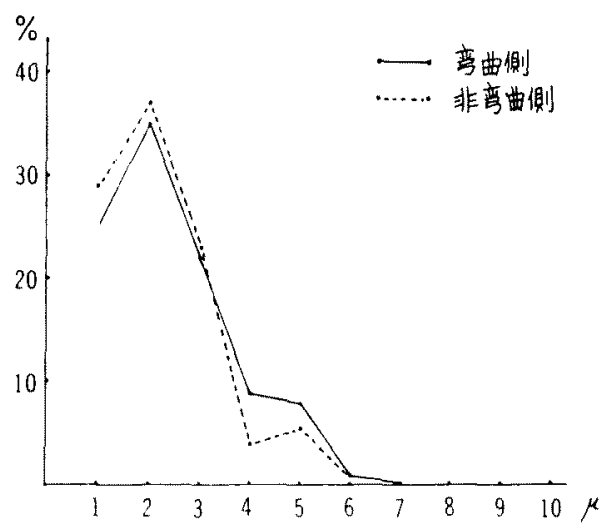

として分禾し，它の大きさの平均は鸽曲側 $3.1 \mu$, 非整曲 側 $2.4 \mu$ である，天蓋(第11 図) では両者とも $2 \mu$ の

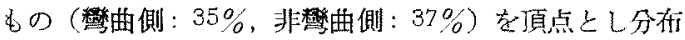

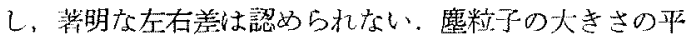

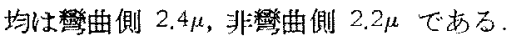

\section{紷括之考安}

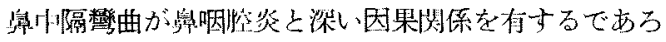
らことは，踠床上から容易に推定されるとこるである

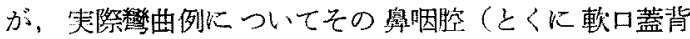
面）を精查してみると，拲曲側に対応した舅咽腔部は他 側に比して，炎定がより惹起しやすい傾向があるわ，原 して該例に打ける摩腔通気の左右差を客観的に測定して

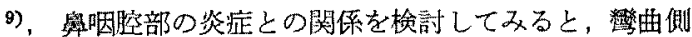
片側通気障害が高度になる程，上述のことがら（竻曲側 
に糊る舆咽腔炎の局在性）が顕著になることが明らか になつた10)

このような現象は，战側通気障害のため鼻咽腙に翼篗 気流が発生し，架気中の麇埃・稩菌等の付着状態が異る ため発来したものであるらと想定して本筷駼を行つた。

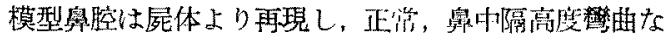

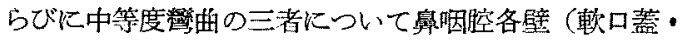
耳管隆起・天蓋）の磨埃付着状態を観察した。

正常鼻腔における鼻咽腔の歴埃付着状態は量的には軟 口蓋が最る付着しやすく 鷹粒子の大きさも他の部に比 して大きいものが付着する。次で耳管隆起, 天蓋の順に

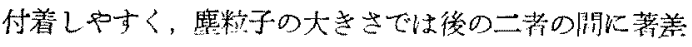
はない

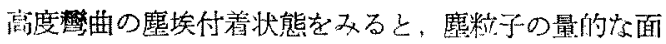

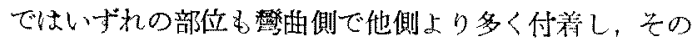
差山軟口蓋で最も著しい 尶粒子の大きさの相異炕上る 分布では，禁曲側て対伈した軟口蓋では，他側の該部上 り比較的大きいものが認めら机るが，耳管隆起，天蕗で は著しい差はない。

中等度彎曲に扎いても，高度禁曲に批惊る程著明では ないが付着麈埃の量拉よび大きさの相異による分布上

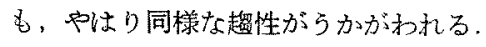

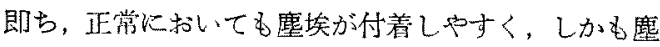
粒子の比較的大きいものが見られるのは軟口蓋であり，

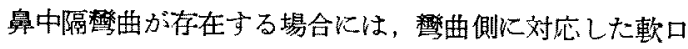
蓋部でこの現象が更に著しくなることが解つた。

このことから勢曲側における鼻咽腔炎の易在性の成立 機転炕あずかる因子として，告に》考察した「整曲側 通気障害が，鷔曲側鼻咽腔部に塵埃等をより付着せしぬ ることが大きな割役を瀆している」といらことが証明さ れたとい充よう。

元来鼼咽腔はその解剖学，生理学上，鹿埃の付着しや すい場所であつて，富井2）模型実験により主として 息腔内蝔埃付着様相を検討し，その中で蝔埃は各部一様 に付着しているのではなくをれが多量に付着するの

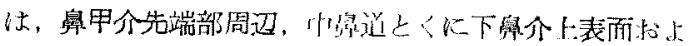
び究咽腔部であるとのべている。

このような麼粒子の周壁付着機転についてては，富井が Findeisen ${ }^{6)}$ の考光方を地用して詳細に考察している。 Findeisen は肺拉よび上気道に批ける空中浮游粒子の 周壁付着にあずかる機樯として「ブラウン連動」「沈下 作用」「辺縁効果」「隋性力」の現象をあげた。 これ

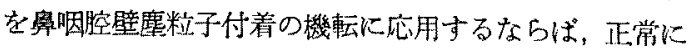

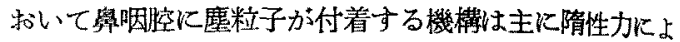

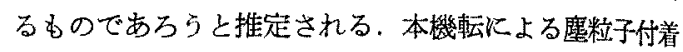
の確率は，粒子の直径が大きく，流管が細く，粒子速度 が大きい程大となり，また流路の屈曲度が強い程，その 麇䊀于付着の確率は大きくなる。この条件にもつとも命

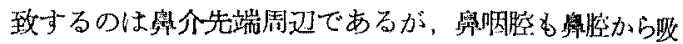
迅まれた空気が大きく屈曲してト方晌う場所であるた

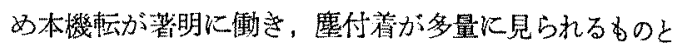
考觉られる. 更に軟口蓋・耳管隆起・天蓋の順に大きい 䊀子が付着するのは，沈下作用によるもので，舅咽腙通

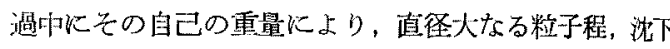
付着しやすくなるものと思われる。この現象は富井が鼻 腙で観察した，上部上り娜次鼻腔底に向らに従い直経大 なる粒子が增加するといら成續と類似している。

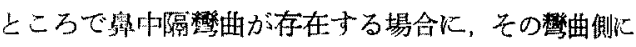

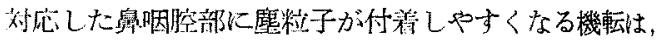
上記のもの加总て更に複雑となり，その考察はむつかし い、しかしながら，例总ば Proetz 1) も記載している如 ， 口経一定の真直な管を空気が一定速度で通過する时 は乱滧が起らないが，管が曲つている場合には空父の流 れは方を変え乱流が㧍こり，空気中の磨埃は壁に付着 するそそしてその付着する場所は曲つたところでなく， それを越したすぐ distal の場所であり，屈曲が著しく なると乱流は更につよくなり付着塵埃も著明になる。こ の現象は impingement effect と呼ばれ，管を曲げる 代りにその一部を細くしても同様なことが起る．この場 合の付着麇埃は，管を細くした部分のすぐ distal に拉 いて見られる。この上らな現象は当然上気道炕適底 されるもので，既述の如き塵埃付着状態は，鼻中滆慧

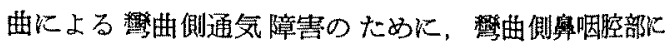
impingement effect あるいはそれに類似した現象が発 米したるのと考えることができる。

また impingenent effect は温気化富えだ空気の場合 には，impingement point 飞水滴を付着せしめるが， 逆に畭いた空気の場合には，この部に乾燥をすたらすで

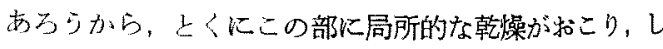

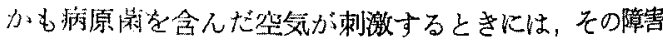
は更に高度となる．何故なら Proetz のいら如く，乾燥 といらことは線毛運動にとつても，線毛上皮細胞自身に とつても致命的であり，もしこのような局所颙燥が生し

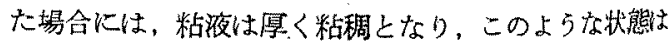
細菌の增殖，浸襲に好条件となると考兄られるからで ある。 
蝔埃は環境衛生の立場からは，呼吸器を通じて最もそ の有害性を発揮するるのであるが，その大きさでは $10 \mu$ 以上ものは殆えど問題とされず，上気道に代着するもの は $5 \mu \sim 10 \mu$ のむのが大部分であるとされている た室内・空気中の細菌は比較的大きい粒子の塵埃に伴つ て存在する場合が多く，細菌数は粗粒子歴埃量に注淁比 例するといわれるき．このよらな観点から私達の行つた 実験をかんがみるに，模型鼻腔に上るるのではあるが正 常なる場合には堹口蓋，奥中隔禁曲が存在する場合には

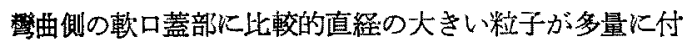
着しやすい㥧向を喼めたといらことは興味あることと思 われる。

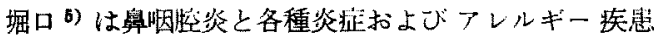
との因果関保を指摘しているが，その中で畄咽腔は㖸埃 や細菌の呼吸に上つて炎症にかかりやすく，乙かも一旦 炎症に浸された場合には，治潦以外には比較的治诲しが たいのが特徽であるとのべているが，上述の考察からも

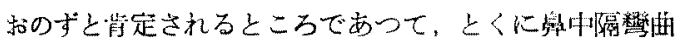

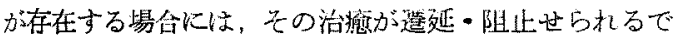
あるらことは充分に理解されるところである。

\section{おわりに}

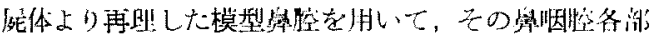

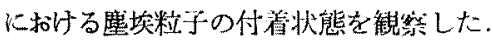

正常なる場合は，軟口盖で粒子が付着しやすく，その 経も比較的大きいるのが多い，鼻中隔彎曲が存在する場 合は，第曲側に対応した畚咽腔部で同様な現象が認めら れ，その左右差は㜞口蓋に执いて最も著明であつた。
これらのことに，以前よりの一連の研究結果を加味し

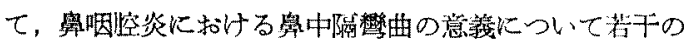
考察を行つた。

\section{公考文献}

1) Proetz. A.W: Air current in the upper respiratory tract and their clinical importance. Ann. of O.R.L. $60: 439,1951 ， 2$ 2) 葟井日出丸，腔の 鷹埃除去機能に 関する研究，耳臨：48：121，1955（昭 30，。3）川崎近太郎，末永泉二。瑥境衙生学，南山

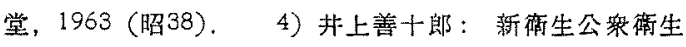
学, 第 4 版, 南山堂, 1961 (昭36)。 5) 堀口电作: 睤咽腔炎の臨床，耳臨，58:5，1965（昭40)。6）2） 上り引用, Findeisen, W: Pflüger's Arch. f.d.g. Physiologie 236Bd, 3Heft, 1935 . 7) 讲出竸夫：影 離細胞像より又大奥咽腔炎の局在性と鵕中隔彎曲, 日耳 奥，67：283，1964（炤39）。8）井出站夫：同（知

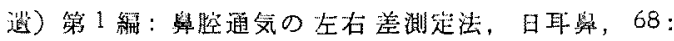
$153 ， 1965$ (昭40)。9）井出站夫：同第 2 絀：禹中

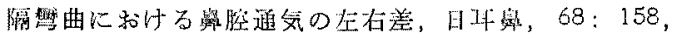

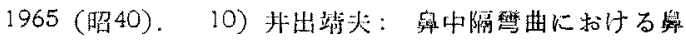

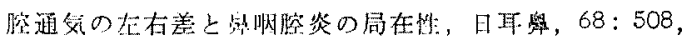
1965 (畍40)。

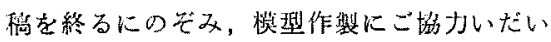
た本学模型室の皆様に感謝します。

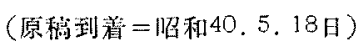

